\title{
Association of Genetic Variants of ELMO1 Gene With Diabetic Nephropathy in the North Indian Population
}

\section{Gurvinder Singh}

Guru Nanak Dev University

\section{Rubina Sharma}

Guru Nanak Dev University

\section{Priyanka Raina}

Guru Nanak Dev University

\section{Vishali Kalotra}

Guru Nanak Dev University

\section{Harkirat Sandhu}

Guru Nanak Dev University

\section{Itty Sethi}

Shri Mata Vaishno Devi University

\section{Varun Sharma}

Shri Mata Vaishno Devi University

\section{Ruhi Sikka}

Guru Nanak Dev University

\section{Kawaljit Matharoo}

Guru Nanak Dev University

Jasmine Sokhi

Guru Nanak Dev University

\section{Ajay Marwaha}

Shriman Hospital, Kapurthala Chownk, Jalandar, Punjab, India

\section{Vipin Vig}

Sohan Singh Eye Hospital, Hall Gate, Amritsar, Punjab, India

\section{Rohit Kapoor}

Heart Station and Diabetic Clinic, Amritsar, Punjab

\section{Manoj Choudhary}

Kidney Hospital and Life Line Medical Institution, Jalandhar, Punjab

\section{Virinder Singh}

Kidney Clinic and Dialysis Centre, Amritsar, Punjab

\section{Sapna Soneja}


Department of Microbiology, Govt. Medical College, Amritsar, Punjab

\section{Swarkar Sharma}

Shri Mata Vaishno Devi University

Amarjit Bhanwer ( $\sim$ ajsbhanwer@gmail.com )

Department of Human Genetics, Guru Nanak Dev University, Amritsar, Punjab, India

\section{Research Article}

Keywords: Diabetic nephropathy (DN), engulfment and cell motility 1 (ELM01), haemodialysis, BMI Posted Date: December 14th, 2020

DOl: https://doi.org/10.21203/rs.3.rs-121795/v1

License: (9) This work is licensed under a Creative Commons Attribution 4.0 International License. Read Full License 


\section{Abstract}

Diabetic nephropathy (DN) is a major cause of renal failure globally including chronic kidney disease and end-stage renal disease (ESRD). Using comprehensive linkage disequilibrium mapping, we genotyped five polymorphisms from engulfment and cell motility 1 (ELMO1) gene (rs741301, rs7799004, rs1882080, rs11769038 and rs1345365) to evaluate its association with DN. BMI was observed to be low in DN cases as compared to the control groups, which is the result of haemodialysis and high doses of medication. Physical inactivity, lipid profile, urea and creatinine were observed to be the confounding factors correlated with DN. This study comprehensively evaluated ELMO1 in DN patients, T2D without Nephropathy and healthy controls from North Indian population and revealed significant association with DN. Haplotypes G-G-C-C and G-A-T-T provided 2-fold risk towards DN development. In conclusion, the present study suggests the significant role of ELMO1 gene polymorphisms in the pathophysiology of DN in North-Indian population.

\section{Introduction}

Diabetic nephropathy (DN) is a multifactorial renal disorder triggered by hyperglycaemia-induced damage to kidney in genetically predisposed individuals. It is the major microvascular complication of type 2 diabetes (T2D) leading to end stage renal failure (ESRD) ${ }^{1}$. Furthermore, IDF also reported the 10 -fold increased risk of ESRD development in T2D patients, suggesting chronic hyperglycaemia as a leading aetiological factor in DN development ${ }^{2}$. DN is characterized with persistent albuminuria and a progressive decline in the glomerular filtration rate, hence, renal function, reducing the overall quality of life ${ }^{3}$. The increase in risk is linked with hypertension, duration of diabetes and the degree of glycemic control. Environmental and genetic factors must, therefore, play entwined roles in the pathogenesis of DN 4 .

Increased prevalence of DN amongT2D individuals from South Asian populations like India has been reported ${ }^{5}$ with the higher incidence of micro- and macro-albuminuria among urban T2D individuals ${ }^{6}$. This can be attributed to rapid urbanization, demographic evolution, rural-to-urban migration, high fat nutrition and sedentary lifestyle along with genetic predisposition ${ }^{7}$. High body fat percentage is correlated with increased inflammation, insulin resistance and higher risk of diabetes, predisposing Indian population to metabolic derangements ${ }^{8}$. Hence, it has become evident that inflammatory mechanisms contribute significantly to the development and progression of DN. These include the lymphocyte and macrophage infiltration of renal compartments with cytokines/chemokines production in the kidney 9,10 . Genetic variants involved in inflammatory pathway have demonstrated strong positive association with the pathogenesis of T2D and DN ${ }^{11-13}$.

Genome-wide SNP genotyping analysis on a large cohort of Japanese patients with T2D identified engulfment and cell motility 1 gene (ELMO1) as a candidate gene conferring susceptibility to $\mathrm{DN}^{14}$. The ELMO1 gene locus 7p14, is a mammalian homologue of the C. elegans gene, ced-12, vital for cell 
migration and engulfment of apoptotic cells ${ }^{15}$. ELMO1 has also been reported to promote phagocytosis and changes in cell morphology. Additional studies on mouse model of chronic glomerulonephritis demonstrated the increased expression of ELMO1, emphasizing its plausible role in the development of glomerular disorders, including DN ${ }^{16}$. Studies on different ethnic groups like African Americans ${ }^{17}$, American Indians ${ }^{18}$, South Indians ${ }^{19}$, European Americans ${ }^{20,21}$ and Chinese ${ }^{22}$ have positively replicated ELMO1 association with $\mathrm{DN}^{2}$. while others failed to report the same for DN and T2D in Indian as well as other ethnicities ${ }^{23-25}$.

The ethnicity specific distribution of the single nucleotide polymorphism (SNPs) can influence the disease susceptibility ${ }^{5}$. Due to ethnic disparity in genetic studies, the present case-control association study is the first study to elucidate the role of selected five SNPs (rs741301, rs7799004, rs1882080, rs11769038 and rs1345365) of ELMO1 gene in DN pathogenesis among DN cases and controls from North Indian population. In the present study, these five polymorphisms from ELMO1 gene were selected after reviewing the literature and the information available in public databases such as dbSNP ${ }^{26}$ and Haploreg ${ }^{27}$. Furthermore, these variants were reported in the aetiology of T2D, its secondary complications like DN and other metabolic disorders as shown in Fig. 1. Thus, were included in this study to investigate their role in the development of DN in presently studied North Indian population.

\section{Results}

\section{Demographic and clinical parameters}

A total of 1584 samples were included in this study, comprising of 344 DN cases, 1240 non-diabetic nephropathic controls (NDN) 9970 healthy controls which are non-nephropathic and non-T2D (NDNT) and 270 were T2D without Nephropathy disease controls]. Baseline characteristics of the DN cases and control groups are shown in Table 1. It was observed that males were more affected with DN as compared to females. The family history of T2D was observed to be the highest among the T2D without Nephropathy controls. Alcohol consumption and smoking were observed to be highest in T2D without Nephropathy (Data not shown) controls while, BMI was observed to be highest in T2D without Nephropathy controls and lowest in DN cases.

The clinical parameters- BMI, SBP and RBS showed significant difference in all the three comparisons except DBP which showed the significant difference only in DN cases vs. T2D without Nephropathy controls. In case of biochemical parameters- $\mathrm{CHO}, \mathrm{LDL}$, urea and creatinine showed significant difference in all three comparisons, whereas, TriG and VLDL showed non-significant difference when DN cases were compared with NDNT controls. In univariate analysis for continuous parameters, it was observed that except for age, DBP and HDL, all other parameters (BMI, SBP, CHO, TriG, VLDL, LDL, serum urea, serum creatinine and RBS) were significantly associated with DN. However, when multivariate analysis was performed on the significantly associated parameters, only TriG, LDL and serum creatinine showed significant association with DN. The significance level was retained even after Bonferroni correction 
(corrected $p$-value $=0.0055$, Supplementary Table S1). Univariate analysis and multivariate regression of binary parameters revealed that alcohol, physical inactivity, diet and gender retained their significant association with the disease after Bonferroni correction, (corrected $p$-value $=0.01$, Supplementary Table S2).

\section{Principal Component Analysis (pca)}

Demographic, anthropometric and biochemical parameters constitute a major component responsible for the development of the disease. Thus, principal component analysis (PCA) was performed to highlight the role of demographic (age, gender, alcohol, smoking and dietary patterns), anthropometric (BMI) and biochemical (CHO, TriG, HDL, VLDL, LDL, urea, creatinine, RBS) factors in the development and progression of DN (Supplementary Table S3). The contribution of each factor in the development of the disease is shown in Supplementary Table S4. PCA revealed five factors i.e. Factor 1 (triglyceride and VLDL); Factor 2 (CHO and LDL); Factor 3 (SBP and DBP), Factor 4 (Serum Urea and Creatinine) and Factor 5 (BMI), contribute ( 70\%) to the DN development (Supplementary Table S3).

\section{Genotype and allele distribution of ELMO1 SNPs}

The allele and genotype frequencies of five SNPs in ELMO1 gene and their association with DN are shown in the Table 2.

rs741301 $(T>C)$. The comparison of DN cases vs. NDN controls revealed that rs741301 ( $T>C)$ was significantly associated $\left(p\right.$-value $\left.=1.27 \times 10^{-5}\right)$ with DN. A significant association $\left[p\right.$-value $=1.92 \times 10^{-6}$, $\mathrm{OR}=1.52(1.28-1.81)]$ was observed for C-allele distribution, which conferred 1.52 fold risk towards $D N$. rs741301 showed significant association ( $p$-value $=1.49 \times 10^{-6}$ ) with DN, when DN cases were compared with NDNT controls. The allelic distribution also showed significant association with DN $[p$-value $=1.74 \times$ $\left.10^{-7}, \mathrm{OR}=1.61(1.35-1.93)\right]$ and conferred 1.61 fold risk towards DN. Further, the comparison in DN cases with T2D without Nephropathy rs741301 did not show any significant association with DN. The SNP rs741301 followed the recessive model and C-allele was observed to be significantly associated with DN when compared with NDN and NDNT control groups in the studied population, respectively. It revealed that recessive model genotype, $C C$ conferred 1.83 fold risk $\left[p\right.$-value $=7.03 \times 10^{-5}, \mathrm{OR}=1.83(1.35-2.47)$ ] and 1.97 fold risk $\left[p\right.$-value $\left.=2.01 \times 10^{-5}, \mathrm{OR}=1.97(1.44-2.71)\right]$ towards $\mathrm{DN}$ when compared DN vs. NDN controls and NDNT controls respectively. However, no significant association of the SNP with DN was observed when the DN cases were compared with T2D without Nephropathy (Table 2).

rs7799004 ( $(\mathrm{C})$ ). On comparing DN cases vs. NDN controls, rs7799004 was observed to be significantly associated $\left(p\right.$-value $\left.=7.06 \times 10^{-12}\right)$ with $\mathrm{DN}$. The distribution of $\mathrm{C}$-allele frequency also showed significant association and conferred 1.55-fold risk $\left[p\right.$-value $\left.=1.33 \times 10^{-6}, \mathrm{OR}=1.55(1.30-1.85)\right]$ towards DN development. The comparison of DN cases with NDNT controls revealed that rs7799004 was significantly associated $\left(p\right.$-value $\left.=1.50 \times 10^{-13}\right)$ with $\mathrm{DN}$. The allele frequency distribution also showed 
significant association with DN $\left[p\right.$-value $\left.=8.51 \times 10^{-8}, \mathrm{OR}=1.65(1.37-1.98)\right]$ and C-allele was observed to confer 1.65-fold risk towards DN. The comparison of genotypes in DN cases and T2D without Nephropathy controls revealed that rs7799004 was significantly associated ( $p$-value $=0.0071$ ) with DN. Model analyses revealed that, $C C$ genotype showed 3.13 fold risk $\left[p\right.$-value $=9.37 \times 10^{-13}, \mathrm{OR}=3.13(2.26-$ $4.34)], 3.76$ fold risk $\left[p\right.$-value $\left.=1.39 \times 10^{-14}, \mathrm{OR}=3.76(2.64-5.36)\right]$ and 1.92 fold risk $[p$-value $=0.0033$, $\mathrm{OR}=1.92(1.24-2.97)]$ towards $\mathrm{DN}$ development respectively.

rs1882080 ( $\mathrm{G}>\mathrm{A})$. On comparing DN cases with NDN controls a significant association was observed ( $p$ value $\left.=6.79 \times 10^{-6}\right)$ with $\mathrm{DN}$. The A-allele distribution also observed to be significantly associated with DN $[p$-value $=0.001, \mathrm{OR}=1.34(1.13-1.58)]$ and provided 1.34 -fold risk towards $\mathrm{DN}$. On comparing DN cases with NDNT controls it was observed that rs1882080 was significantly associated ( $p$-value $=1.72 \times$ $\left.10^{-5}\right)$, with $\mathrm{DN}$. The allele frequency distribution also reflected a significant risk associated [( $p$-value $=$ $0.0007, \mathrm{OR}=1.35(1.14-1.62)]$ with $\mathrm{DN}$. On comparing genotypes of $\mathrm{DN}$ cases and T2D without Nephropathy controls it was observed that rs 1882080 was significantly associated with DN ( $p$-value $=$ $\left.4.35 \times 10^{-7}\right)$. The model analyses showed that genotype AA showed approximately 2 folds risk in all the three comparisons viz. $\left[p\right.$-value $\left.=1.33 \times 10^{-6}, \mathrm{OR}=2.01(1.51-2.68)\right]$, $\left[p\right.$-value $=3.13 \times 10^{-6}, \mathrm{OR}=$ $2.01(1.49-2.72)]$ and $\left[p\right.$-value $\left.=5.08 \times 10^{-5}, \mathrm{OR}=2.0(1.43-2.81)\right]$ respectively.

rs11769038 $(G>T)$. The comparison of DN cases vs. NDN controls revealed that rs11769038 was significantly associated ( $p$-value $=0.0006)$ with $D N$. The G-allele frequency distribution also showed significant association $[p$-value $=0.022, \mathrm{OR}=1.27(1.03-1.56)$ ] and provided 1.27 -fold risk towards $\mathrm{DN}$. The comparison of DN cases vs. NDNT controls revealed that rs 11769038 was significantly associated $\left(p\right.$-value $\left.=1.19 \times 10^{-5}\right)$ with DN. The allele frequency distribution showed significant association with DN $\left[p\right.$-value $\left.=1.12 \times 10^{-5}, \mathrm{OR}=1.59(1.29-1.95)\right]$ and G-allele provided 1.59-fold risk towards DN. The genotypic comparison of DN cases vs. T2D without Nephropathy controls revealed that rs 11769038 was significantly associated with DN ( $p$-value $\left.=5.92 \times 10^{-11}\right)$. The distribution of allele showed significant association $\left[p\right.$-value $=1.22 \times 10^{-7}, \mathrm{OR}=2.48(1.76-3.51)$ ] and T-allele was observed to confer 2.48-fold risk towards DN development. The model analyses revealed that genotype GG conferred 1.40-fold risk [ $p$ value $=0.0028, \mathrm{OR}=1.40(1.14-1.92)]$ towards $\mathrm{DN}$ development only when compared DN cases vs. NDNT controls.

rs1345365 (G >A). The evaluation of DN cases with NDN controls revealed that rs1345365 showed significant association ( $p$-value $=1.31 \times 10^{-9}$ ) with $\mathrm{DN}$ development. Allele frequency was also observed to be associated with $\mathrm{DN}\left[p\right.$-value $\left.=7.45 \times 10^{-13}, \mathrm{OR}=2.02(1.66-2.46)\right]$ and G-allele provided 2.02-fold risk towards DN. The comparison of DN cases vs. NDNT controls revealed that rs 1345365 showed significant association $\left(p\right.$-value $=5.61 \times 10^{-20}$ ) with $\mathrm{DN}$ development. The allele frequency distribution showed significant association $\left[p\right.$-value $\left.=3.84 \times 10^{-24}, \mathrm{OR}=2.73(2.24-3.33)\right]$ and $\mathrm{A}$-allele provided an increased risk of 2.73-fold towards DN. The comparison of genotypes in DN cases and T2D without Nephropathy controls revealed significant association $\left(p\right.$-value $\left.=7.29 \times 10^{-4}\right)$ with DN development. 
Allelic association revealed significant association $\left[p\right.$-value $\left.=2.38 \times 10^{-15}, \mathrm{OR}=5.02(3.27-7.71)\right]$ with DN and A-allele conferred 5.02-fold risk towards the development of DN. Under model analyses recessive model genotype GG conferred 2.02 fold risk $\left[p\right.$-value $\left.=5.82 \times 10^{-6}, \mathrm{OR}=2.02(1.56-2.61)\right]$, $[p$-value $=1.28$ $\left.\times 10^{-18}, \mathrm{OR}=3.24(2.48-4.24)\right]$ conferred 3.24 fold risk and 3.83 fold increased risk $[p$-value $=0.0015$, OR $=3.83(1.58-9.30)]$ towards DN development respectively towards the development of DN. In this group ELMO1 polymorphisms significantly associated with $D N$ and retained the level of significance even after Bonferroni correction ( $p$-value $=0.0033$, while rs7799004, lost its significance after correction.

\section{Haplotype Analyses}

ELMO1 gene haplotype frequencies (rs11769038, rs1882080, rs741301, rs7799004, and rs1345365) for all the compared groups are given in the Table 3 . The sequence of haplotypes is in the direction of rs11769038, rs1882080, rs741301, and rs7799004. The polymorphism rs 1345365 was not in LD with any of the other polymorphism thus was omitted from the haplotype analysis. The haplotypes G-G-C-C and GA-T-T provided 2.40 fold [OR $=2.40(2.0-2.87)]$ and 2.17 fold [OR $=2.17(1.76-2.68)]$ risk with $p$-value of $1.09 \times 10^{-22}$ and $1.21 \times 10^{-13}$ for DN, respectively. In the comparison of DN cases vs. NDNT controls the haplotype G-G-T-T $\left[p\right.$-value $\left.=5.31 \times 10^{-26}, \mathrm{OR}=0.089(0.05-0.15)\right]$ attributed protection towards DN whereas, haplotype T-A-T-T ( $p$-value $=0.21$ ) did not show any association with DN. It was observed that haplotypes G-G-C-C and G-A-T-T were significantly associated with high risk for DN with odds ratio of 2.54 $95 \% \mathrm{Cl}=2.11-3.06)$ and $3.38(95 \% \mathrm{Cl}=2.67-4.27)$ with $p$-value of $1.49 \times 10^{-23}$ and $2.48 \times 10^{-26}$

respectively when compared with NDNT control group. However, the haplotypes T-A-T-T [ $p$-value $=6 \times 10^{-}$ $\left.{ }^{4}, \mathrm{OR}=0.70(0.57-0.86)\right]$ and G-G-T-T $\left[p\right.$-value $\left.=3.59 \times 10^{-27}, \mathrm{OR}=0.08(0.05-0.15)\right]$ attributed protection towards DN (DN vs. NDNT). While comparing DN cases with T2D without Nephropathy controls, haplotypes G-G-C-C $\left[p\right.$-value $\left.=1.8 \times 10^{-8}, \mathrm{OR}=2.05(1.59-2.64)\right]$ and T-A-T-T $\left[p\right.$-value $=8.3 \times 10^{-9}, \mathrm{OR}=$ $3.27(2.15-4.98)$ ] presented a 2.05 fold and 3.27 fold increased risk towards the development of $D N$, respectively. The haplotype G-A-T-T $\left[p\right.$-value $\left.=6 \times 10^{-4}, \mathrm{OR}=0.70(0.57-0.86)\right]$ was attributing protection against DN. Haplotype G-G-T-T did not show significant association $[p$-value $=0.31,0 \mathrm{R}=0.87(0.68-1.13)$ ] with DN (Fig. 2).

\section{Rna Secondary Structure Prediction}

Elucidation of RNA structure and the access to correctly annotated RNA structure is of great importance, especially in the predictions of its secondary and 3D structures ${ }^{28}$. Protein secondary structure and initiation codon in the mRNA are known to influence the translation efficiency ${ }^{29}$. Therefore, in the present study, the RNA secondary structure of the wild allele and mutant allele of the ELMO1 gene polymorphisms with reference allele were analysed. There was a slight reduction in the energy of the wild type allele as compared to the variant type allele as shown in the Fig. 3 . The changes in their structure of 
wild type and mutant are shown in the enclosed circle. There is a slight decrease in the free energy for each polymorphism, thus causing the change in the secondary structure of RNA after folding.

\section{Discussion}

DN is characterized by morphological and ultra-structural changes in the kidney including expansion of the molecular matrix and loss of the charge barrier on the glomerular basement membrane ${ }^{30,31}$. It accounts for the $40-50 \%$ patients with ESRD and approximately $20 \%$ of diabetic ESRD patients subsequently undergo renal transplant ${ }^{32}$. T2D is one of the leading causes of kidney failure. Hyperglycemia induces hyperfiltration, a predictor of progressive kidney disease and morphologic changes in the kidneys that ultimately lead to podocyte damage and loss of filtration surface ${ }^{2}$. The results are further linked with increase in observed disease-associated risk factors like RBS, BMI, urea, creatinine and lipid parameters, thereby suggesting their crucial role in DN susceptibility. Higher percentage of males affected with DN pinpoints the sexual dimorphism in DN progression accredited to the role of sex hormones where androgen is thought to elevate the intra-glomerular pressure and proximal sodium reabsorption while oestrogen provides protection ${ }^{33}$. The impact of renal disease on public health is accelerating, and early education, detection, intervention, and risk-factor control are needed to address the burden of DN and its adverse measures in the vulnerable populations ${ }^{34}$.

This is the first study that strongly suggests the association of five polymorphisms of ELMO1 with DN in the North Indian population (Fig. 3). Novelty of this study also lies in the categorization of controls into three groups (NDN, NDNT and T2D without Nephropathy disease controls), which generate better association of confounding factors and genotypes/alleles with DN. ELMO1 is a proinflammatory gene that has been identified as a putative candidate for DN pathophysiology in a Genome-wide SNP genotyping study on a Japanese cohort ${ }^{14}$. In the present study, we found significant association of rs741301 ( $>$ > C) polymorphism with DN in comparison with NDN controls and NDNT controls; and Callele provided 1.5 and 1.6 -fold increased risk towards $D N$, respectively. These results are in concordance with a previous study from North India that has also reported a significant association of rs 741301 between DN cases and T2D without Nephropathy controls ${ }^{23}$. Other studies have also observed significant association for rs 741301 polymorphism in South Indian ${ }^{35}$, Chinese ${ }^{22}$, Japanese ${ }^{14}$ and Iranian population ${ }^{36}$ between DN cases and T2D without Nephropathy controls. On contrary, T allele emerged as casual variant in the Chinese population suggesting allelic heterogeneity ${ }^{22}$. However, other studies did not replicate the association of rs741301 polymorphism in American Indians, Malaysian, Chinese and Indian subgroups of diabetic nephropathy in a comparison of DN cases and T2D without Nephropathy controls ${ }^{18,37,38}$.

The polymorphism rs7799004 showed significant association with DN which are in accordance to Pezzolesi et al. (2009) from European population in T1D patients, reporting a significant association [ $p$ value $=0.02, \mathrm{OR}=1.26(1.03-1.53)]$ of rs7799004 with ESRD in T2D patients, but are contrasting to that of Hanson et al. (2010) who have found no association of DN with rs7799004 in American Indian 
population. This is the first study to report the association of rs7799004 (T >C) polymorphism in Indian population and can be considered as first baseline data for future studies in different ethnicities of India. Another SNP rs1882080 ( $\mathrm{G}>\mathrm{A}$ ) reflected a significant association with DN; genotype AA conferred 2.01fold risk towards DN. The results of present study are similar to a previous study in European population which has also observed a significant risk associated with rs1882080 ( $\mathrm{G}>\mathrm{A}$ ) polymorphism in diabetic nephropathy ${ }^{21}$. They have also demonstrated that rs 1882080 in combination with polymorphism rs11769038 showed a strong risk towards development of DN. In accordance to the previous study, we also observed increased risk provided by AA genotype of rs1882080 towards development of DN.

The current study demonstrated a significant association of rs11769038 with DN in all three comparisons and G-allele distribution showed significant risk towards DN. The results of present study are in accordance with a previous study on European (Caucasian) T1D subjects in which a strong association of rs $11769038(\mathrm{G}>\mathrm{T})$ polymorphism of ELMO1 gene with DN was observed ${ }^{21}$, while it is contradictory to another study which has demonstrated non-significant association of rs 11769038 polymorphism with DN in Chinese population ${ }^{22}$. The differences with Chinese population can be due to the wide range of difference in ethnic and cultural backgrounds of two populations with the addition of the role of environment in it. In our study, the G-allele of rs1345365 (G > A) variant provided 2 fold risk towards DN aetiology consistent with another study, which has also shown significant association for DN under dominant genetic model in African-American population ${ }^{17}$. Intriguingly, a study on Mexicans have reported protective role of this polymorphism emphasizing the notion of allelic heterogeneity ${ }^{39}$. However, other studies on American Indians and Chinese population did not report any association with rs 1345365 (G > A) polymorphism of ELMO1 gene ${ }^{18,22}$.

The conflict in results of various studies can be attributed to unknown aetiology of DN, multiple genetic factors, environmental factors, ethnicity differences, sample size variation and selection of control groups. T2D represents an intermediate disease stage between healthy controls and overt DN cases. The present association suggest the role of prolonged hyperglycaemia in causation of nephropathy and highlights the importance of considering T2D cases as internal controls in assessment of genetic architecture of DN.

Previously, there were fewer studies available on the role of ELMO1gene polymorphisms in T2D but the DN data suggested that ELMO1 may have an imperative role in the development of nephropathy in T2D patients, which might be contributing to renal function decline ${ }^{21}$. Later, different studies from different populations confirmed that ELMO1 variants are primarily associated with the risk of proteinuria. Several functional studies have even demonstrated that ELMO1 contributes to the progression of chronic glomerular injury through its dysregulation of extracellular matrix (ECM) metabolism, resulting in renal ECM accumulation ${ }^{16}$. This accumulation contributes to both glomerular and tubular basement membrane thickening, which are the main hallmarks of advanced DN ${ }^{40}$. Other studies have also reported the association of intronic variants in ELMO1 gene but the variants in their study are different from those reported in the present study except for one polymorphism (rs1345365) ${ }^{14,17}$. These associations at 
ELMO1 across each study represent allelic heterogeneity contributed by diverse ancestral genetic backgrounds of the different ethnic groups ${ }^{21}$. The findings of the present study suggest that role of ELMO1 gene may be implicated in the development of DN.

In imputation of SNPs first studied polymorphisms and then NCBI_GIH genotypes were phased independently and then the two types of datasets were merged and were phased again. This phased data was used as the reference for the imputations. Concordance rate for each SNP was measured to check the accuracy of imputation. Numbers of SNPs involved in imputation ranged from 1-3 for five SNPs. Imputation has revealed that the highest concordance rates were observed for rs741301 (89.6\%) and rs 7799004 (86.1\%), while rest were observed to be below $70 \%$, whereas did not show any results for rs 1345365 . The average concordance rate of the SNPs was observed to be $76.4 \%$ (Supplementary Table S5). Accuracy of imputation is known to increase with the increase in reference population size and also by including the familial genotype data in the reference population ${ }^{41}$. The sample size of the reference population is not large, but the numbers of SNPs were good enough to make a conclusion that the accuracy of the present data is of good quality.

ELMO1, haplotypes G-G-C-C and G-A-T-T conferred risk towards the development of DN, in DN vs. NDN controls, while the haplotype T-A-T-T and G-G-T-T conferred risk in DN cases vs. T2D without Nephropathy controls, but provided protection in DN cases vs. NDNT controls. The variants rs741301 and rs7799004 $\left(D^{\prime}=0.99, r^{2}=0.97\right), r s 741301$ and $r s 1882080\left(D^{\prime}=0.97, r^{2}=0.92\right)$, and $r s 7799004$ and rs1882080 $\left(D^{\prime}=0.97\right.$, $\left.r^{2}=0.92\right)$ were observed to be in strong LD in DN cases. A study in African-American population has also observed that rs741301 and rs7799004 were in strong $L D\left(D^{\prime}=1.0\right)$ in their population ${ }^{18}$. In another study, rs 1345365 was observed to be in LD with other two SNPs- rs 1981740 and rs 10951509 , not included in this study. A study in Chinese population and Iranian population, found that polymorphisms- rs 741301 and rs 1345365 were in weak $L D\left(D^{\prime}=0.01\right.$ and $D^{\prime}=0.11$, respectively) with each other ${ }^{22,36}$. But, rs 1345365 was observed in strong LD with rs11769038 $\left(D^{\prime}=0.91\right)$ in Chinese population ${ }^{22}$. The polymorphism rs1345365 was not observed to be in LD with any of the studied polymorphisms in the present study. The major problem in comparison with other studies is that the markers selected for analysis are not same among all the previously studied populations which lead to the divergence of the results in different studies. The conflict in results in various studies reflect that association of different haplotype blocks and LD patterns with the disease risk may vary among populations due to diverse genetic backgrounds, complex aetiology of the disease, variation in sample sizes and heterogeneity in samples; and selection of different polymorphisms/markers. Also LD is the non-random distribution of alleles in the general population, which may be the cause that rs7799004 and rs11769038 were not in LD in case of NDNT (healthy) controls while showing mild LD in DN cases and T2D without nephropathy controls. Thus, indicating that rs7799004 and rs11769038 are following normal distribution in healthy individuals and were showing mild LD in DN cases as well as T2D without nephropathy controls.

The limitation of the present study is the functional relevance of ELMO1. To overcome this limitation, prediction of the secondary RNA structures of studied polymorphisms using bioinformatics approach, 
supported the risk causal role of ELMO1 in DN pathophysiology.

\section{Conclusion}

ELMO1 gene polymorphisms are significantly associated with DN thus intimating its pivotal role in DN pathogenesis in North Indian population along with the elevated diabetogenic risk factors and kidney function markers-urea and creatinine. Gender based differences were reported, predisposing males towards the susceptibility of DN. The haplotypes G-G-C-C and G-A-T-T are strongly associated with DN development. The study also highlights the importance of ethnicity and recruitment of appropriate control groups in genetic association studies. However, further studies are warranted to validate the functional aspect of this gene and its comprehensive mechanism in the aetiology of DN.

\section{Research Design And Methods}

Study Participants. The present study included total of 1584 subjects from North India, comprising of age-matched 344 DN cases, 1240 non-diabetic nephropathic controls (NDN) [970 healthy controls which are non-nephropathic and non-T2D (NDNT) and 270 were T2D without Nephropathy disease controls]. This study was approved by the Ethics Committee of Guru Nanak Dev University, Amritsar (Letter No.-229/HG). Informed consent was obtained from all participants and/or their legal guardians and study has been carried out in accordance with the Declaration of Helsinki.

T2D was defined by the criteria of the American Diabetes Association-2014. Most of DN patients at the time of enrolment were under the treatment of dialysis whereas T2D without Nephropathy were prescribed with oral hypoglycaemic agents, or insulin, or both. Blood pressure was measured after 20 minutes of rest Omron (HEM-711 model) digital machine. Various demographic and anthropometric parameters like age, gender, family history of T2D \& DN, alcohol consumption, smoking and BMI were noted for DN cases and three control groups. BMI classification was made according to cut off values for Asian Indian adults $\left(23 \mathrm{~kg} / \mathrm{m}^{2}\right)$ given by Snehalatha et al, (2003) ${ }^{42}$. Written informed consent was taken from all individuals before participation in the study.

DNA extraction and Clinical parameters. The genomic DNA was extracted from the blood samples using inorganic extraction ${ }^{43}$. Quantification and quality estimation of genomic DNA was done by UV spectrophotometer (Eppendorf Biospectrometer-Basic) and agarose gel electrophoresis. Blood samples were analysed for random blood sugar using glucometer (Accu-Check Active). Levels of urea, creatinine, total cholesterol (TC), triglycerides (TG), and high-density lipoprotein cholesterol (HDL-C) were measured from plasma by using commercial kits (Erba Chem 7 analyzer). Very low density lipoprotein (VLDL) and low density lipoprotein (LDL) were calculated by using the formulae given by Friedewald et al. in $1972{ }^{44}$.

SNP selection and Genotyping. Genotyping was performed using high throughput Sequenom iPLEX Gold for Sequenom MassARRAY platform. 
Statistical analyses. Baseline parameters were compared using unpaired student's $t$-test. Hardy Weinberg equilibrium was checked for all the SNPs, at first six polymorphisms were included in the study but of the six polymorphisms, one (rs7785934) was not following HWE thus was excluded from further analyses. Chi-square test was performed to compare the distribution of genotype/allele and genotype models of ELM01 SNPs between DN cases and controls (IBM SPSS Inc., version 20.0; Chicago, IL, USA). The extent of association between ELMO1 SNPs was determined using Odds ratio (OR) at 95\% confidence interval (Cl) with $p$-value $<0.05$. Haplotype and Linkage disequilibrium (LD) analysis was performed using Haploview (version 4.2) ${ }^{45}$. One of the polymorphism (rs1345365) was not in LD and thus was excluded from the analyses. Power of the present study was $>80 \%$ calculated using PS software (version 3.0) ${ }^{46}$. The imputation of the selected markers was performed using Plink v1.07 47 , with the reference data downloaded from NCBI as NCBI_GIH with 2737 genetic markers of ELMO1 gene in 103 individuals. Locations of five single nucleotide polymorphisms were identified from dbSNP browser and then the SNP data was merged with GIH data obtained from NCBI. RNA structures and their free energies were obtained using RNA fold software available online (http://rna.tbi.univie.ac.at/cgi-bin/RNAWebSuite/RNAfold.cgi). 
Table 1

Comparison of Demographic, Biochemical, Anthropometric parameters in DN cases $(n=344)$, NDN controls $(n=1240)$, NDNT controls $(n=970)$ and T2D without Nephropathy controls $(n=270), D N-$ Diabetic Nephropathy, T2D-Type 2 Diabetes, BMI-Body Mass Index, SBP-Systolic Blood Pressure, DBP-Diastolic Blood Pressure, CHO-Cholesterol, TriG.-Triglyceride, HDL-High Density Lipoproteins, LDL-Low Density Lipoproteins, VLDL-Very Low Density Lipoproteins, RBS-Random Blood Sugar, SDStandard Deviation, T2D w/o N - T2D without Nephropathy, $p$-value $<0.05$ is considered significant

\begin{tabular}{|c|c|c|c|c|c|c|c|}
\hline Parameters & Mean \pm & & & & $\begin{array}{l}\text { DN } \\
\text { Cases } \\
\text { vs. NDN } \\
\text { Controls }\end{array}$ & $\begin{array}{l}\text { DN Cases } \\
\text { vs. NDNT } \\
\text { Controls } \\
\text { (Healthy } \\
\text { controls) }\end{array}$ & $\begin{array}{l}\text { DN Cases vs. } \\
\text { T2D w/o N } \\
\text { Controls } \\
\text { (Disease } \\
\text { Control) }\end{array}$ \\
\hline & $\begin{array}{l}\text { DN } \\
\text { Cases }\end{array}$ & $\begin{array}{l}\text { NDN } \\
\text { Controls }\end{array}$ & $\begin{array}{l}\text { NDNT } \\
\text { Controls }\end{array}$ & $\begin{array}{l}\text { T2D } \\
\text { W/o N } \\
\text { Controls }\end{array}$ & $p$-value & $p$-value & $p$-value \\
\hline Age (yrs) & $\begin{array}{l}57.97 \\
\pm 6.62\end{array}$ & $\begin{array}{l}57.21 \pm \\
10.44\end{array}$ & $\begin{array}{l}57.07 \pm \\
10.68\end{array}$ & $\begin{array}{l}57.96 \pm \\
9.47\end{array}$ & 0.215 & 0.124 & 0.980 \\
\hline $\begin{array}{l}\mathrm{BMI} \\
\left(\mathrm{kg} / \mathrm{m}^{2}\right)\end{array}$ & $\begin{array}{l}23.26 \\
\pm 3.98\end{array}$ & $\begin{array}{l}25.29 \pm \\
4.36\end{array}$ & $\begin{array}{l}24.97 \pm \\
4.30\end{array}$ & $\begin{array}{l}26.40 \pm \\
4.39\end{array}$ & $\begin{array}{l}2.06 \times \\
10^{-4}\end{array}$ & $\begin{array}{l}2.32 \times 10^{-} \\
11\end{array}$ & $4.17 \times 10^{-21}$ \\
\hline $\begin{array}{l}\text { SBP } \\
(\mathrm{mmHg})\end{array}$ & $\begin{array}{l}138.12 \\
\pm 18.02\end{array}$ & $\begin{array}{l}130.41 \\
\pm 15.77\end{array}$ & $\begin{array}{l}127.88 \\
\pm 14.34\end{array}$ & $\begin{array}{l}135.07 \\
\pm 17.18\end{array}$ & $\begin{array}{l}3.17 x \\
10^{-8}\end{array}$ & $\begin{array}{l}3.46 \times 10^{-} \\
19\end{array}$ & 0.025 \\
\hline $\begin{array}{l}\text { DBP } \\
(\mathrm{mmHg})\end{array}$ & $\begin{array}{l}83.73 \\
\pm 10.86\end{array}$ & $\begin{array}{l}84.07 \pm \\
8.87\end{array}$ & $\begin{array}{l}82.68 \pm \\
7.53\end{array}$ & $\begin{array}{l}86.64 \pm \\
10.47\end{array}$ & 0.590 & 0.103 & $4.25 \times 10^{-4}$ \\
\hline $\begin{array}{l}\mathrm{CHO} \\
(\mathrm{mg} / \mathrm{dl})\end{array}$ & $\begin{array}{l}143.24 \\
\pm 44.81\end{array}$ & $\begin{array}{l}166.32 \\
\pm 49.01\end{array}$ & $\begin{array}{l}163.68 \\
\pm 47.97\end{array}$ & $\begin{array}{l}170.90 \\
\pm 50.53\end{array}$ & $\begin{array}{l}1.69 \times \\
10^{-14}\end{array}$ & $\begin{array}{l}1.48 \times 10^{-} \\
10\end{array}$ & $1.33 \times 10^{-13}$ \\
\hline $\begin{array}{l}\text { TriG. } \\
\text { (mg/dl) }\end{array}$ & $\begin{array}{l}180.07 \\
\pm 116.4\end{array}$ & $\begin{array}{l}207.4 \pm \\
141.76\end{array}$ & $\begin{array}{l}178.72 \\
\pm \\
109.32\end{array}$ & $\begin{array}{l}256.98 \\
\pm 174.3\end{array}$ & $\begin{array}{l}4.6 \times \\
10^{-4}\end{array}$ & 0.860 & $9.96 \times 10^{-11}$ \\
\hline $\begin{array}{l}\mathrm{HDL} \\
(\mathrm{mg} / \mathrm{dl})\end{array}$ & $\begin{array}{l}47.25 \\
\pm 25.81\end{array}$ & $\begin{array}{l}48.78 \pm \\
24.36\end{array}$ & $\begin{array}{l}48.12 \pm \\
21.92\end{array}$ & $\begin{array}{l}49.92 \pm \\
28.09\end{array}$ & 0.322 & 0.585 & 0.197 \\
\hline $\begin{array}{l}\text { VLDL } \\
(\mathrm{mg} / \mathrm{dl})\end{array}$ & $\begin{array}{l}36.01 \\
\pm 23.29\end{array}$ & $\begin{array}{l}41.63 \pm \\
28.49\end{array}$ & $\begin{array}{l}35.98 \pm \\
22.2\end{array}$ & $\begin{array}{l}51.40 \pm \\
34.86\end{array}$ & $\begin{array}{l}3.40 x \\
10^{-4}\end{array}$ & 0.984 & $9.96 \times 10^{-11}$ \\
\hline $\begin{array}{l}\text { LDL } \\
(\mathrm{mg} / \mathrm{dl})\end{array}$ & $\begin{array}{l}68.15 \\
\pm 39.19\end{array}$ & $\begin{array}{l}82.13 \pm \\
42.57\end{array}$ & $\begin{array}{l}83.78 \pm \\
43.09\end{array}$ & $\begin{array}{l}79.12 \pm \\
41.49\end{array}$ & $\begin{array}{l}1.07 x \\
10^{-7}\end{array}$ & $5.62 \times 10^{-8}$ & 0.001 \\
\hline $\begin{array}{l}\text { Urea } \\
\text { (mg/dl) }\end{array}$ & $\begin{array}{l}127.28 \\
\pm 45.13\end{array}$ & $\begin{array}{l}36.03 \pm \\
20.55\end{array}$ & $\begin{array}{l}34.09 \pm \\
21.34\end{array}$ & $\begin{array}{l}38.53 \pm \\
19.23\end{array}$ & $\begin{array}{l}4.05 x \\
10^{-30}\end{array}$ & $\begin{array}{l}1.29 \times 10^{-} \\
30\end{array}$ & $2.17 \times 10^{-29}$ \\
\hline $\begin{array}{l}\text { Creatinine } \\
(\mathrm{mg} / \mathrm{dl})\end{array}$ & $\begin{array}{l}7.71 \pm \\
2.21\end{array}$ & $\begin{array}{l}1.00 \pm \\
0.76\end{array}$ & $\begin{array}{l}0.92 \pm \\
0.81\end{array}$ & $\begin{array}{l}1.09 \pm \\
0.67\end{array}$ & $\begin{array}{l}7.9 \times \\
10^{-140}\end{array}$ & $\begin{array}{l}9.6 \times 10^{-} \\
145\end{array}$ & $4.61 \times 10^{-136}$ \\
\hline $\begin{array}{l}\text { RBS } \\
\text { (mg/dl) }\end{array}$ & $\begin{array}{l}189.79 \\
\pm 67.62\end{array}$ & $\begin{array}{l}154.25 \\
\pm 37.81\end{array}$ & $\begin{array}{l}119.0 \pm \\
20.86\end{array}$ & $\begin{array}{l}216.56 \\
\pm 68.8\end{array}$ & 0.027 & $\begin{array}{l}1.25 \times 10^{-} \\
52\end{array}$ & $3.98 \times 10^{-6}$ \\
\hline
\end{tabular}




\begin{tabular}{|c|c|c|c|c|c|c|}
\hline Parameters & Mean \pm SD & & & $\begin{array}{l}\text { DN } \\
\text { Cases } \\
\text { vs. NDN } \\
\text { Controls }\end{array}$ & $\begin{array}{l}\text { DN Cases } \\
\text { vs. NDNT } \\
\text { Controls } \\
\text { (Healthy } \\
\text { controls) }\end{array}$ & $\begin{array}{l}\text { DN Cases vs. } \\
\text { T2D w/o N } \\
\text { Controls } \\
\text { (Disease } \\
\text { Control) }\end{array}$ \\
\hline $\begin{array}{l}\text { Duration of } \\
\text { Diabetes } \\
\text { (yrs) }\end{array}$ & $\begin{array}{l}13.49 \\
\pm 7.57\end{array}$ & - & $\begin{array}{l}9.21 \pm \\
7.47\end{array}$ & - & - & $2.29 \times 10^{-27}$ \\
\hline
\end{tabular}


Table 2

Distribution of genotype, allele frequencies and model analysis of ELMO1 SNPs in DN cases vs. NDN controls, ${ }^{1} \mathrm{DN}$ vs.NDN, ${ }^{2} \mathrm{DN}$ vs. NDNT and ${ }^{3} \mathrm{DN}$ vs. T2D without Nephropathy, OR - Odds Ratio, $\mathrm{Cl}-$ Confidence Interval, ${ }^{\mathrm{a}} p=$ genotypic $p$-value, ${ }^{\mathrm{b}} p=$ allelic $p$-value, $p$-value $<0.05$ is considered significant

\begin{tabular}{|c|c|c|c|c|c|c|c|c|c|c|}
\hline \multirow{2}{*}{$\begin{array}{l}\text { Polymorphisms } \\
\begin{array}{l}\text { Allele } \\
\text { Distribution }\end{array}\end{array}$} & \multicolumn{2}{|c|}{$\begin{array}{l}\text { rs741301 (T } \\
>C)\end{array}$} & \multicolumn{2}{|c|}{$\begin{array}{l}\text { rs77999004 (T } \\
>C)\end{array}$} & \multicolumn{2}{|c|}{$\begin{array}{l}\text { rs1882080 } \\
(G>A)\end{array}$} & \multicolumn{2}{|c|}{$\begin{array}{l}\text { rs11769038 } \\
(G>T)\end{array}$} & \multicolumn{2}{|c|}{$\begin{array}{l}\text { rs1345365 (G } \\
>A)\end{array}$} \\
\hline & $\mathrm{T}$ & C & $T$ & C & G & A & G & $T$ & G & $A$ \\
\hline $\begin{array}{l}\text { DN Cases }(n= \\
344)\end{array}$ & 0.52 & 0.48 & 0.59 & 0.41 & 0.52 & 0.48 & 0.76 & 0.24 & 0.72 & 0.28 \\
\hline $\begin{array}{l}\text { NDN Controls } \\
(n=1240)\end{array}$ & 0.62 & 0.38 & 0.69 & 0.31 & 0.59 & 0.41 & 0.71 & 0.29 & 0.55 & 0.45 \\
\hline $\begin{array}{l}\text { NDNT Controls } \\
(\mathrm{n}=970)\end{array}$ & 0.64 & 0.36 & 0.70 & 0.30 & 0.60 & 0.40 & 0.66 & 0.34 & 0.48 & 0.52 \\
\hline $\begin{array}{l}\text { T2D without } \\
\text { Nephropathy } \\
(n=270)\end{array}$ & 0.58 & 0.42 & 0.64 & 0.36 & 0.58 & 0.42 & 0.89 & 0.11 & 0.93 & 0.07 \\
\hline \multirow[t]{2}{*}{$\begin{array}{l}\text { DN cases vs. } \\
\text { NDN Controls }\end{array}$} & \multicolumn{2}{|c|}{${ }_{5}^{\mathrm{a}} p=1.27 \times 10^{-}$} & \multicolumn{2}{|c|}{$\begin{array}{l}{ }^{\mathrm{a}} p=7.06 \times 10^{-} \\
12\end{array}$} & \multicolumn{2}{|c|}{$\begin{array}{l}{ }^{a} p=6.79 \times \\
10^{-6}\end{array}$} & \multicolumn{2}{|c|}{${ }^{\mathrm{a}} p=0.0006$} & \multicolumn{2}{|c|}{${ }_{9}^{\mathrm{a}} p=1.31 \times 10^{-}$} \\
\hline & \multicolumn{2}{|c|}{$\begin{array}{l}{ }^{\mathrm{b}} p=1.92 \times 10^{-} \\
6, \mathrm{OR}= \\
1.52(1.28- \\
1.81)\end{array}$} & \multicolumn{2}{|c|}{$\begin{array}{l}{ }^{\mathrm{b}} p=1.33 \times 10^{-} \\
6, \mathrm{OR}= \\
1.55(1.20- \\
1.85)\end{array}$} & \multicolumn{2}{|c|}{$\begin{array}{l}{ }^{\mathrm{b}} p=0.001 \\
\mathrm{OR}= \\
1.34(1.13- \\
1.58)\end{array}$} & \multicolumn{2}{|c|}{$\begin{array}{l}\mathrm{OR}= \\
1.27(1.03- \\
1.56)\end{array}$} & \multicolumn{2}{|c|}{$\begin{array}{l}{ }^{\mathrm{b}} p=7.45 \times 10^{-} \\
13, \mathrm{OR}= \\
2.02(1.66- \\
2.46)\end{array}$} \\
\hline \multirow[t]{2}{*}{$\begin{array}{l}\text { DN cases vs. } \\
\text { NDNT Controls }\end{array}$} & \multicolumn{2}{|c|}{${ }_{6}^{\mathrm{a}} p=1.49 \times 10^{-}$} & \multicolumn{2}{|c|}{$\begin{array}{l}{ }_{13}^{a} p=150 \times 10^{-} \\
\end{array}$} & \multicolumn{2}{|c|}{$\begin{array}{l}{ }^{\mathrm{a}} p=1.72 \times \\
10^{-5}\end{array}$} & \multicolumn{2}{|c|}{${ }_{5}^{\mathrm{a}} p=1.19 \times 10^{-}$} & \multicolumn{2}{|c|}{${ }_{20}^{a} p=5.61 \times 10^{-}$} \\
\hline & \multicolumn{2}{|c|}{$\begin{array}{l}{ }^{\mathrm{b}} p=1.74 \times 10^{-} \\
7, \mathrm{OR}= \\
1.61(1.35- \\
1.93)\end{array}$} & \multicolumn{2}{|c|}{$\begin{array}{l}{ }^{\mathrm{b}} p=8.51 \times 10^{-} \\
\mathbf{8}^{8}, \mathrm{OR}= \\
1.65(1.37- \\
1.98)\end{array}$} & \multicolumn{2}{|c|}{$\begin{array}{l}{ }^{\mathrm{b}} p=0.0007 \\
\mathrm{OR}= \\
1.35(1.13- \\
1.62)\end{array}$} & \multicolumn{2}{|c|}{$\begin{array}{l}{ }^{\mathrm{b}} p=1.12 \times 10^{-} \\
5, \mathrm{OR}= \\
1.59(1.29- \\
1.95)\end{array}$} & \multicolumn{2}{|c|}{$\begin{array}{l}{ }^{\mathrm{b}} p=3.84 \times 10^{-} \\
24, \mathrm{OR}= \\
2.73(2.24- \\
3.33)\end{array}$} \\
\hline \multirow[t]{3}{*}{$\begin{array}{l}\text { DN cases vs. } \\
\text { T2D without } \\
\text { Nephropathy }\end{array}$} & \multicolumn{2}{|c|}{${ }^{\mathrm{a}} p=0.0568$} & \multicolumn{2}{|c|}{${ }^{\mathrm{a}} p=0.0071$} & \multirow{2}{*}{\multicolumn{2}{|c|}{$\begin{array}{l}{ }^{\mathrm{a}} p=4.35 \times \\
10^{-7}\end{array}$}} & \multirow{2}{*}{\multicolumn{2}{|c|}{$\begin{array}{l}{ }_{11}^{\mathrm{a}} p=5.92 \times 10^{-} \\
\end{array}$}} & \multirow{2}{*}{\multicolumn{2}{|c|}{${ }_{4}^{\mathrm{a}} p=7.29 \times 10^{-}$}} \\
\hline & \multicolumn{2}{|c|}{${ }^{\mathrm{b}} p=0.0568$} & \multicolumn{2}{|c|}{${ }^{\mathrm{b}} p=0.072$} & & & & & & \\
\hline & $\begin{array}{l}\mathrm{OR}= \\
1.25(\mathrm{C} \\
1.58)\end{array}$ & & $\begin{array}{l}\mathrm{OR}= \\
1.24( \\
1.58)\end{array}$ & & $\begin{array}{l}0=0.1 \\
\mathrm{OR}= \\
1.26(1 \\
1.60)\end{array}$ & $0-$ & $\begin{array}{l}p=1 . \\
7, \mathrm{OR} \\
2.48( \\
3.51)\end{array}$ & $6-$ & $\begin{array}{l}p=2 \\
15, \text { of } \\
5.02( \\
7.71)\end{array}$ & $7-$ \\
\hline Risk Allele & C & & C & & A & & $\mathbf{G}$ & & G & \\
\hline $\begin{array}{l}\text { Genotype } \\
\text { Model }\end{array}$ & $\begin{array}{l}\text { Reces } \\
\text { (CC/T }\end{array}$ & $\begin{array}{l}\text { ve } \\
+\mathrm{TC})\end{array}$ & $\begin{array}{l}\text { Rece } \\
\text { (CC/7 }\end{array}$ & $\begin{array}{l}\text { ive } \\
+\mathrm{TC})\end{array}$ & $\begin{array}{l}\text { Reces } \\
\text { (AAVG } \\
\text { GA) }\end{array}$ & & $\begin{array}{l}\text { Rece: } \\
\text { (GG/ }\end{array}$ & $\begin{array}{l}\text { ve } \\
+\mathrm{GT})\end{array}$ & $\begin{array}{l}\text { Rece } \\
\text { (GG/ }\end{array}$ & $\begin{array}{l}v e \\
+G A)\end{array}$ \\
\hline
\end{tabular}




\begin{tabular}{|c|c|c|c|c|c|}
\hline Polymorphisms & $\begin{array}{l}\text { rs741301 (T } \\
>C)\end{array}$ & $\begin{array}{l}\text { rs77990004 (T } \\
>C)\end{array}$ & $\begin{array}{l}\text { rs1882080 } \\
(G>A)\end{array}$ & $\begin{array}{l}\text { rs11769038 } \\
(G>T)\end{array}$ & $\begin{array}{l}\text { rs1345365 (G } \\
>A)\end{array}$ \\
\hline \multirow{2}{*}{$\begin{array}{l}\text { DN cases vs. } \\
\text { NDN Controls }\end{array}$} & $p=7.03 \times 10^{-}$ & $p=9.37 \times 10^{-}$ & $p=1.33 x$ & $p=0.4947$ & $p=5.82 \times 10^{-8}$ \\
\hline & $\begin{array}{l}\mathrm{OR}= \\
1.83(1.35- \\
2.47)\end{array}$ & $\begin{array}{l}\text { OR }= \\
3.13(2.26- \\
4.34)\end{array}$ & $\begin{array}{l}\mathrm{OR}= \\
2.01(1.51- \\
2.68)\end{array}$ & $\begin{array}{l}\mathrm{OR}= \\
1.09(0.85- \\
1.40)\end{array}$ & $\begin{array}{l}\mathrm{OR}= \\
2.02(1.56- \\
2.61)\end{array}$ \\
\hline \multirow{3}{*}{$\begin{array}{l}\text { DN cases vs. } \\
\text { NDNT Controls }\end{array}$} & $p=2.01 \times 10^{-}$ & $p=1.66 \times 10^{-}$ & $p=3.13 x$ & \multirow{3}{*}{$\begin{array}{l}p=0.0028 \\
\text { OR }= \\
1.40(1.14- \\
1.92)\end{array}$} & \multirow{2}{*}{$\begin{array}{l}p=1.28 \times 10^{-} \\
18\end{array}$} \\
\hline & & & $10^{-6}$ & & \\
\hline & $\begin{array}{l}\text { OR }= \\
1.97(1.44- \\
2.71)\end{array}$ & $\begin{array}{l}\text { OR }= \\
3.76(2.64- \\
5.36)\end{array}$ & $\begin{array}{l}\text { OR }= \\
2.01(1.49- \\
2.72)\end{array}$ & & $\begin{array}{l}\mathrm{OR}= \\
3.24(2.48- \\
4.24)\end{array}$ \\
\hline \multirow{3}{*}{$\begin{array}{l}\text { DN cases vs. } \\
\text { T2D without } \\
\text { Nephropathy }\end{array}$} & $p=0.0799$ & $p=0.0033$ & $p=5.08 \times$ & $p=0.3439$ & $p=0.0015$ \\
\hline & $\mathrm{OR}=$ & $\mathrm{OR}=$ & & \multirow{2}{*}{$\begin{array}{l}\mathrm{OR}= \\
0.60(0.21- \\
1.75)\end{array}$} & \multirow{2}{*}{$\begin{array}{l}\mathrm{OR}= \\
3.83(1.58- \\
9.30)\end{array}$} \\
\hline & $\begin{array}{l}1.44(0.96- \\
2.16)\end{array}$ & $\begin{array}{l}1.92(1.24- \\
2.97)\end{array}$ & $\begin{array}{l}\mathrm{OR}= \\
2.0(1.43- \\
2.81)\end{array}$ & & \\
\hline
\end{tabular}


Table 3

Distribution of Haplotypes observed in the candidate genes in DN cases vs. NDN controls, $p$-value $<0.05$ is considered significant

\section{ELMO1 haplotype rs11769038, rs1882080, rs741301, rs7799004,}

DN cases vs. NDN controls

Haplotypes Frequency in DN Cases

G-G-C-C $\quad 0.458$

T-A-T-T

0.220

0.263

0.244

0.141

G-A-T-T

0.020

0.185

G-G-T-T

0.020

(1)

Frequency in Controls

0.260 p-value

Odds Ratio (95\%,

Cl)

${ }_{22}^{1.09 \times 10^{-}} 2.40(2.0-2.87)$

0.21

$0.87(0.71-1.08)$

$1.21 \times 10^{-}$

$2.17(1.76-2.68)$

13

$5.31 \times 10^{-}$

$0.08(0.05-0.15)$ 26

DN cases vs. NDNT controls

G-G-C-C $\quad 0.46$

0.25

${ }_{23}^{1.49 \times 10^{-}}$

$2.54(2.11-3.06)$

T-A-T-T

0.23

0.30

$6.0 \times 10^{-4}$

$0.70(0.57-0.86)$

G-A-T-T

0.26

0.09

$2.48 \times 10^{-}$

$3.38(2.67-4.27)$

26

G-G-T-T $\quad 0.02$

0.19

$3.59 \times 10^{-}$

$0.08(0.05-0.15)$

27

DN cases vs. T2D without Nephropathy controls

\begin{tabular}{|c|c|c|c|c|}
\hline G-G-C-C & 0.440 & 0.278 & $1.80 \times 10^{-8}$ & $2.05(1.59-2.64)$ \\
\hline T-A-T-T & 0.179 & 0.062 & $8.30 \times 10^{-9}$ & $3.27(2.15-4.98)$ \\
\hline G-A-T-T & 0.296 & 0.324 & $\begin{array}{l}3.28 \times 10^{-} \\
14\end{array}$ & $0.18(0.11-0.29)$ \\
\hline G-G-T-T & 0.030 & 0.151 & 0.3079 & $0.87(0.68-1.13)$ \\
\hline
\end{tabular}

\section{Declarations}

Acknowledgement 
The financial assistance to GS by UGC-UPE Scheme, is acknowledged. Financial support from UGCCPEPA, UGC-UPE to AJSB is acknowledged.

\section{Author Contributions}

G.S., S.S.†† and A.J.S.B. designed the hypothesis. G.S., P.R., V.K., H.S.S., R.S.‡, R.S. $\neq$, S.S.† and J.S. helped in sample collection. G.S., V.K., R.S.‡, I.S., K.M., S.S.t† and A.J.S.B. contributed to the manuscript writing. G.S., V.K., and V.S.\# performed the experiments. G.S., K.M., S.S.t† and A.J.S.B. analysed the results. A.M., V.S.\#\#, V.V., M.C. and R.K. helped in clinical investigation. All the authors reviewed the manuscript and approved the final version.

\section{Declaration}

The authors declare no Conflict of interests

\section{References}

1. CDC. National diabetes fact sheet: national estimates and gneral information on diabetes and prediabetes in the United States. US Depaerment of Health and Human Services, 1-30.

https://www.cdc.gov/diabetes/pdfs/data/statistics/national-diabetes-statistics-report.pdf. (2020).

2. IDF. International Diabetes Federation. Diabetes Res Clin Pract 9, 1-176. (2019).

3. Kumar, S., et al. SNP in KCNQ1 Gene is Associated with Susceptibility to Diabetic Nephropathy in Subjects with Type 2 Diabetes in India. J Assoc Physicians India 66(8), 58-61. Published 2019/07/22. (2018).

4. Dronavalli, S., Duka, I. \& Bakris, G.L. The pathogenesis of diabetic nephropathy. Nat Clin Pract Endocrinol Metab 4(8), 444-452, doi:10.1038/ncpendmet0894 (2008).

5. Chandie Shaw, P.K., et al. South-Asian type 2 diabetic patients have higher incidence and faster progression of renal disease compared with Dutch-European diabetic patients. Diabetes Care 29(6), 1383-1385, doi:10.2337/dc06-0003 (2006).

6. Unnikrishnan, R.I., et al. Prevalence and risk factors of diabetic nephropathy in an urban South Indian population: the Chennai Urban Rural Epidemiology Study (CURES 45). Diabetes Care 30(8), 20192024, doi:10.2337/dc06-2554 (2007).

7. Misra, A. \& Shrivastava, U. Obesity and dyslipidemia in South Asians. Nutrients 5(7), 2708-2733, doi:10.3390/nu5072708 (2013).

8. Yajnik, C.S. \& Ganpule-Rao, A.V. The obesity-diabetes association: what is different in indians? Int J Low Extrem Wounds 9, 113-115. Published 2010/08/14. (2010).

9. Navarro-Gonzalez, J.F. \& Mora-Fernandez, C. The role of inflammatory cytokines in diabetic nephropathy. Journal of the American Society of Nephrology 19, 433-442. Published 2008/02/08. (2008). 
10. Ruster, C. \& Wolf, G. The role of chemokines and chemokine receptors in diabetic nephropathy. Frontiers in Bioscience 13, 944-955. Published 2007/11/06. (2008).

11. Ahluwalia, T.S., et al. Common variants of inflammatory cytokine genes are associated with risk of nephropathy in type 2 diabetes among Asian Indians. PLoS One 4, e5168. Published 2009/04/10. (2009).

12. El-Sherbini, S.M., Shahen, S. M., Mosaad, Y. M., Abdelgawad, M. S. and Talaat, R. M. Gene polymorphism of transforming growth factor-beta1 in Egyptian patients with type 2 diabetes and diabetic nephropathy. Acta Biochim Biophys Sin (Shanghai) 45(4), 330-338, doi:10.1093/abbs/gmt003 (2013).

13. Santos, K.G., et al. Association of eNOS gene polymorphisms with renal disease in Caucasians with type 2 diabetes. Diabetes Res Clin Pract 91(3), 353-362, doi:10.1016/j.diabres.2010.12.029 (2011).

14. Shimazaki, A., et al. Genetic variations in the gene encoding ELMO1 are associated with susceptibility to diabetic nephropathy. Diabetes 54, 1171-1178. Published 2005/03/29. (2005).

15. Gumienny, T.L., et al. CED-12/ELMO, a novel member of the Crkll/Dock180/Rac pathway, is required for phagocytosis and cell migration. Cell 107(1), 27-41, doi:10.1016/s0092-8674(01)00520-7 (2001).

16. Shimazaki, A., et al. ELMO1 increases expression of extracellular matrix proteins and inhibits cell adhesion to ECMs. Kidney Int 70, 1769-1776. Published 2006/10/06. (2006).

17. Leak, T.S., et al. Variants in intron 13 of the ELMO1 gene are associated with diabetic nephropathy in African Americans. Ann Hum Genet 73 s, 152-159. Published 2009/02/03. (2009).

18. Hanson, R.L., et al. ELMO1 variants and susceptibility to diabetic nephropathy in American Indians. Mol Genet Metab 101(4), 383-390, doi:10.1016/j.ymgme.2010.08.014 (2010).

19. Bodhini, D., et al. Association of TCF7L2 Polymorphism with Diabetic Nephropathy in the South Indian Population. Ann Hum Genet 79(5), 373-379, doi:10.1111/ahg.12122 (2015).

20. Craig, D.W., Millis, M.P. \& DiStefano, J.K. Genome-wide SNP genotyping study using pooled DNA to identify candidate markers mediating susceptibility to end-stage renal disease attributed to Type 1 diabetes. Diabet Med 26(11), 1090-1098, doi:10.1111/j.1464-5491.2009.02846.x (2009).

21. Pezzolesi, M.G., et al. Confirmation of genetic associations at ELMO1 in the GoKinD collection

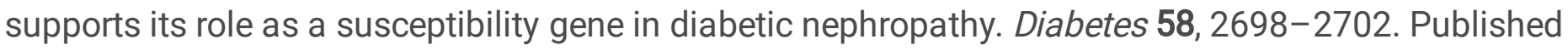
2009/08/05. (2009).

22. Wu, H.Y., et al. Association of ELMO1 gene polymorphisms with diabetic nephropathy in Chinese population. J Endocrinol Invest 36, 298-302. Published 2012/07/31. (2013).

23. Yadav, A.K., Kumar, V., Dutta, P., Bhansali, A. \& Jha, V. Variations in CCR5, but not HFE, ELMO1, or SLC12A3, are associated with susceptibility to kidney disease in north Indian individuals with type 2 diabetes. J Diabetes 6(6), 547-555, doi:10.1111/1753-0407.12128 (2014).

24. Musambil, M. \& Siddiqui, K. Genetics and genomics studies in type 2 diabetes: A brief review of the current scenario in the Arab region. Diabetes Metab Syndr 13(2), 1629-1632, doi:10.1016/j.dsx.2019.03.017 (2019). 
25. Williams, W.W., et al. Association testing of previously reported variants in a large case-control metaanalysis of diabetic nephropathy. Diabetes 61(8), 2187-2194, doi:10.2337/db11-0751 (2012).

26. Sherry, S.T., et al. dbSNP: the NCBI database of genetic variation. Nucleic Acids Res 29(1), 308-311. Published 2000/01/11. (2001).

27. Ward, L.D. \& Kellis, M. HaploReg: a resource for exploring chromatin states, conservation, and regulatory motif alterations within sets of genetically linked variants. Nucleic Acids Res 40 (Database issue), D930-934, doi:10.1093/nar/gkr917 (2012).

28. Zok, T., et al. RNApdbee 2.0: multifunctional tool for RNA structure annotation. Nucleic Acids Res 46(W1), W30-w35, doi:10.1093/nar/gky314 (2018).

29. Sikka, R., et al. TNF-alpha (g.-308 G > A) and ADIPOQ (g. + $45 \mathrm{~T}>\mathrm{G}$ ) gene polymorphisms in type 2 diabetes and microvascular complications in the region of Punjab (North-West India). Curr Eye Res 39, 1042-1051. Published 2014/03/25. (2014).

30. Hovind, P., Rossing, P., Tarnow, L., Smidt, U.M. \& Parving, H.H. Progression of diabetic nephropathy. Kidney Int 59(2), 702-709, doi:10.1046/j.1523-1755.2001.059002702.x (2001).

31. Parving, H.H. Diabetic nephropathy: prevention and treatment. Kidney Int 60(5), 2041-2055, doi:10.1046/j.1523-1755.2001.00020.x (2001).

32. USRDS. Annual Data Report: Atlas of End-Stage Renal Disease in the United States. Bethesda, United States: National Institute of Diabetes and Digestive and Kidney Diseases (NIDDK), National Institutes of Health $(\mathrm{NIH}),(2002)$.

33. Reckelhoff, J.F. \& Granger, J.P. Role of androgens in mediating hypertension and renal injury. Clin Exp Pharmacol Physiol 26(2), 127-131. Published 1999/03/05. (1999).

34. Collins, A.J., et al. US Renal Data System 2012 Annual Data Report. Am J Kidney Dis 61(1 Suppl 1), A7, e1-476, doi:10.1053/j.ajkd.2012.11.031 (2013).

35. Bodhini, D., et al. Association of rs11643718 SLC12A3 and rs741301 ELM01 Variants with Diabetic Nephropathy in South Indian Population. Ann Hum Genet 80(6), 336-341, doi:10.1111/ahg.12174 (2016).

36. Mehrabzadeh, M., et al. Association between ELMO1 gene polymorphisms and diabetic nephropathy in an Iranian population. J Diabetes Metab Disord 15, 43, doi:10.1186/s40200-016-0265-3 (2016).

37. Yahya, M.J., Ismail, P.B. \& Nordin, N.B. Association of CCL2, CCR5, ELM01, and IL8 Polymorphism with Diabetic Nephropathy in Malaysian Type 2 Diabetic Patients. 2053015, doi:10.1155/2019/2053015 (2019).

38. Kim, S., et al. Examination of association with candidate genes for diabetic nephropathy in a Mexican American population. Clin J Am Soc Nephro/ 5(6), 1072-1078, doi:10.2215/cjn.06550909 (2010).

39. Alberto Ramirez-Garcia, S., et al. Association of the ELMO1 gene (snp rs1345365) with development of type 2 diabetes mellitus in the Mexican mestizo population. Invest Clin 56(4), 341-355. Published 2015/12/01. (2015). 
40. Caramori, M.L., et al. Cellular basis of diabetic nephropathy: 1. Study design and renal structuralfunctional relationships in patients with long-standing type 1 diabetes. Diabetes 51, 506-513. Published 2002/01/29. (2002).

41. Sharma, A., et al. Accuracy of Imputation of Microsatellite Markers from BovineSNP50 and BovineHD BeadChip in Hanwoo Population of Korea. Genomics Inform 16(1), 10-13, doi:10.5808/gi.2018.16.1.10 (2018).

42. Snehalatha, C., Viswanathan, V. \& Ramachandran, A. Cutoff values for normal anthropometric variables in asian Indian adults. Diabetes Care 26, 1380-1384. Published 2003/04/30. (2003).

43. Miller, S.A., Dykes, D.D. \& Polesky, H.F. A simple salting out procedure for extracting DNA from human nucleated cells. Nucleic Acids Res 16(3), 1215, doi:10.1093/nar/16.3.1215 (1988).

44. Friedewald, W.T., Levy, R.I. \& Fredrickson, D.S. Estimation of the concentration of low-density lipoprotein cholesterol in plasma, without use of the preparative ultracentrifuge. Clin Chem 18(6), 499-502. Published 1972/06/01. (1972).

45. Barrett, J.C., Fry, B., Maller, J. \& Daly, M.J. Haploview: analysis and visualization of LD and haplotype maps. Bioinformatics 21(2), 263-265, doi:10.1093/bioinformatics/bth457 (2005).

46. Dupont, W.D. \& Plummer, W.D. Power and Sample Size Calculations for studies Involving Linear Regression. Controlled Clinical Trials 19, 589-601. (1998).

47. Purcell, S., et al. PLINK: a tool set for whole-genome association and population-based linkage analyses. Am J Hum Genet 81(3), 559-575, doi:10.1086/519795 (2007).

\section{Figures}




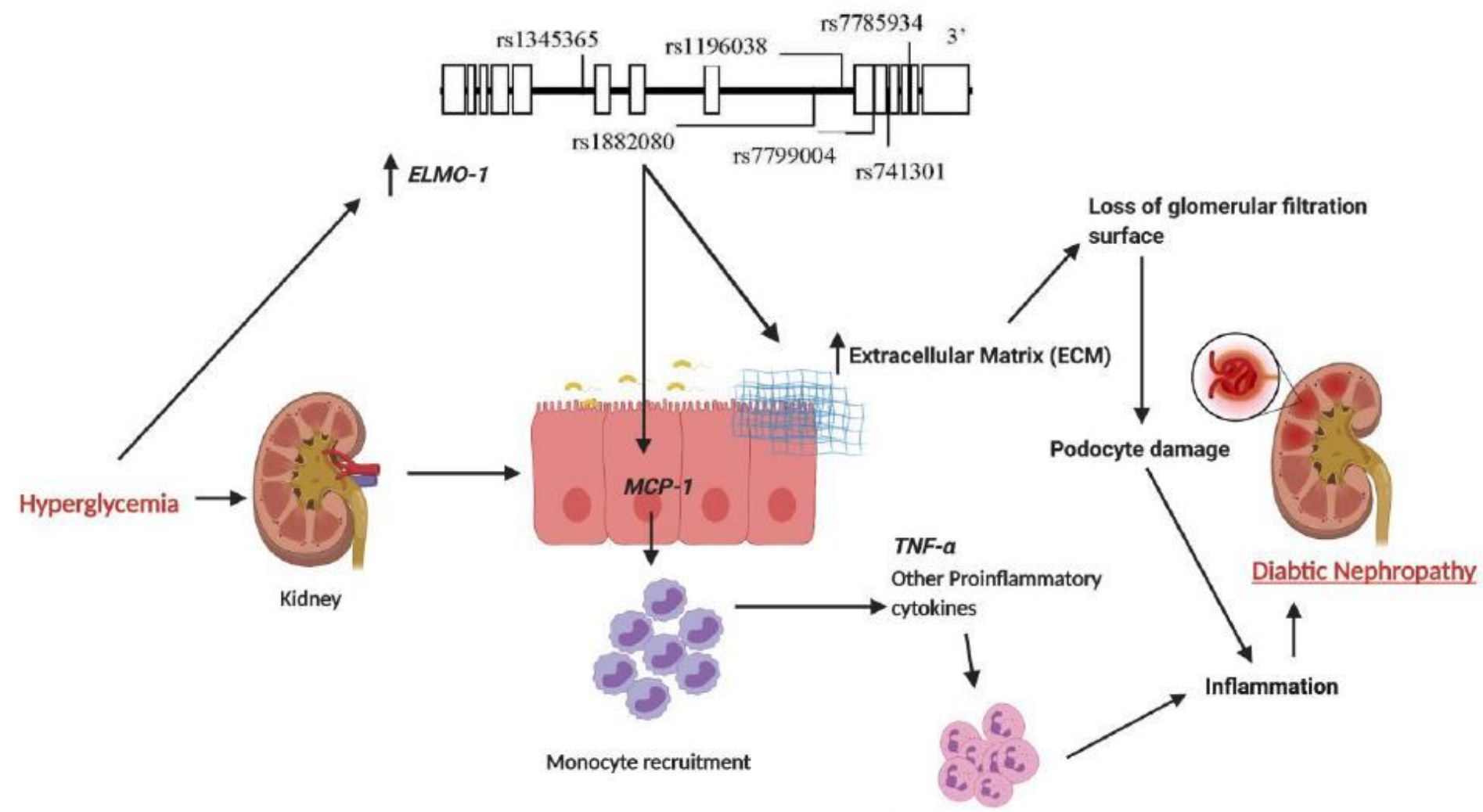

Activation of Neutrophils

\section{Figure 1}

The overall representation of the involvement of ELMO1 gene in the development of DN

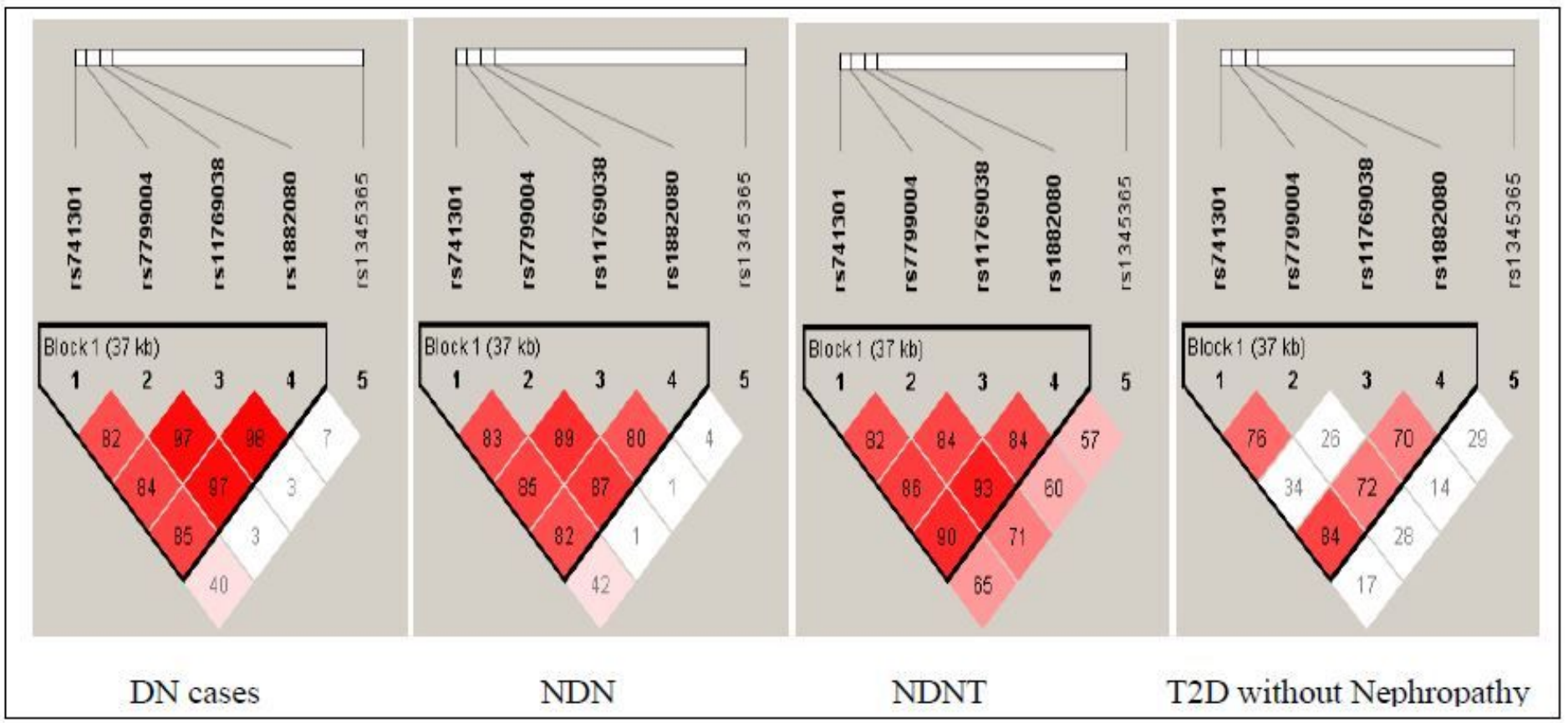

Figure 2 

without Nephropathy controls

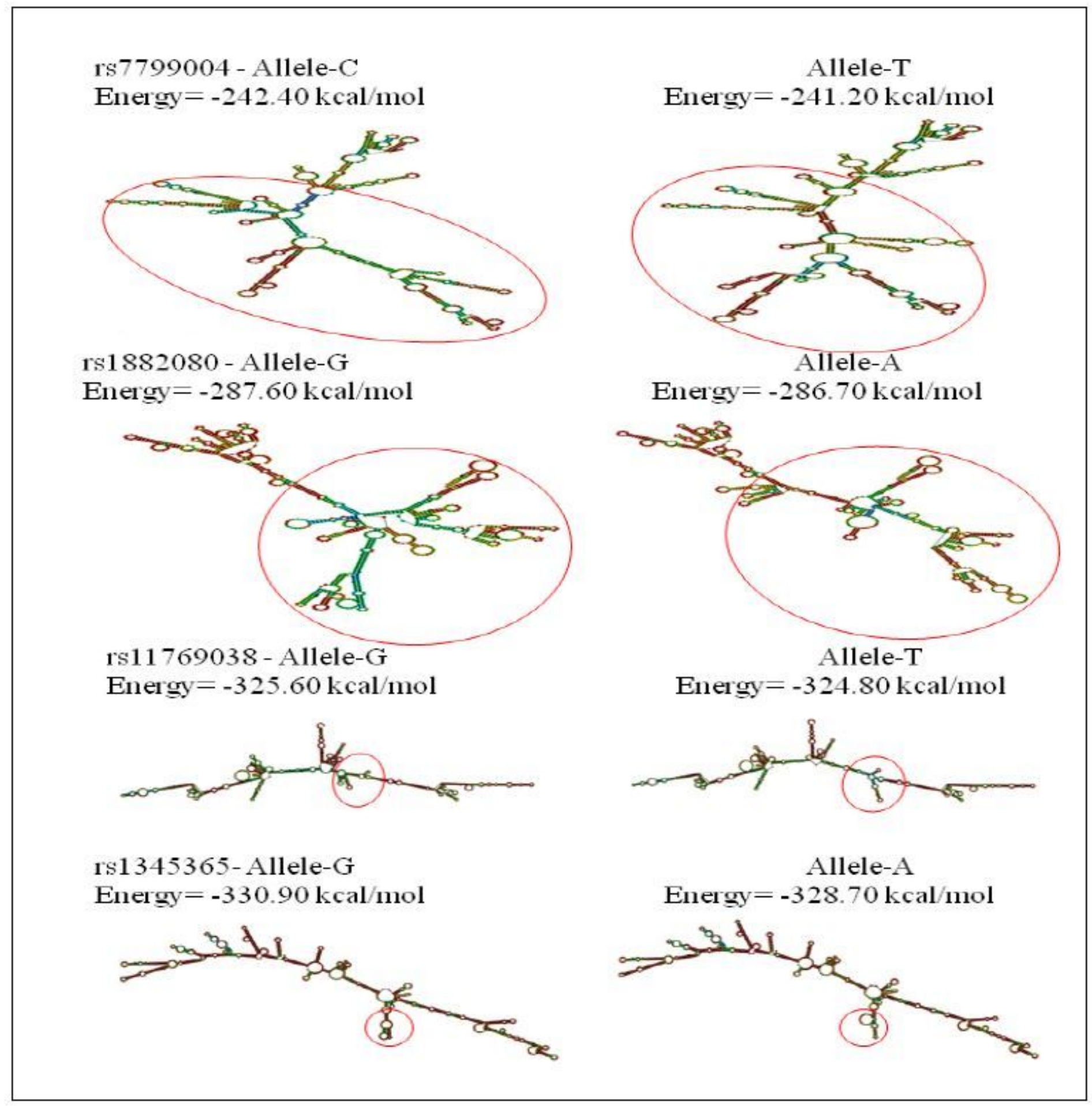

\section{Figure 3}

Predicted RNA secondary structure and energies for ELMO1 calculated by using RNA fold. The polymorphic regions are shown in circle. Free energy of the structures determine the stability of RNA structure 


\section{Supplementary Files}

This is a list of supplementary files associated with this preprint. Click to download.

- Supplementaryfiles.pdf 